\title{
PENGARUH PEMBERIAN BOOKLET KEMOTERAPI TERHADAP KEMAMPUAN PERAWATAN DIRI PENDERITA KANKER PAYUDARA PASCA KEMOTERAPI DI RUANG BEDAH RUMAH SAKIT ABDUL MOELOEK (RSAM) BANDAR LAMPUNG
}

\author{
Anita $^{1}$, Tri Sukamti $\mathbf{P}^{2}$ \\ ${ }^{1}$ Jurusan Keperawatan Poltekkes Tanjungkarang, \\ ${ }^{2}$ Rumah Sakit Abdul Moeloek Bandar Lampung \\ Email: anitabustami@yahoo.co.id
}

\begin{abstract}
Abstrack: Effect Of Chemotherapy Booklet Giving to Self Care Ability of Breast Cancer Patients After Chemotherapy in The Surgical Hospital Abdul Moeloek (RSAM) Bandar Lampung. Riskesdas 2013 the prevalence of cancer in Indonesia in 1000, or approximately 1,4 per 330.000 people, in province of Lampung increased than 0,02\% (2010), 0,04\% (2011) and 2012 at $0,04 \%$ (Riskesdas 2012). Data breast cancer (RSAM) in 2014 as many as 471 (2,7\%) patients. The aim of research to determine the effect of Giving Chemotherapy Booklet Againts Ability Care Breast Cancer after Chemotherapy in Surgery Room in Abdul Moeloek Hospital (RSAM) Bandar Lampung in 2016. The study was conducted starting on January 1-30, 2016 quasi-experimental design with one group, pre-test and post test. The population of 65 women with breast cancer after chemotherapy, a sample of 56 respondents. Data were analyzed by $t$ test dependent. The results obtained by the average value of self-care behaviors of breast cancer patients after chemotherapy before giving booklet was 4,70 with a standard deviation of 1,249 . The average value of the value of self-care behaviors of breast cancer patients after chemotherapy after the booklet was 7,82 with a standard deviation of 1,478 . Statistical test result $\mathrm{p}$ value $=0.000$, meaning at alpha $5 \%$ dismpulkan that there is a significant relationship between self-care behaviors of breast cancer patients after chemotherapy before and after giving of chemotherapy booklet.
\end{abstract}

Keywords: Booklet, Chemotherapy, Breast cancer.

\begin{abstract}
Abstrak: Pengaruh Pemberian Booklet Kemoterapi terhadap Kemampuan Perawatan Diri Penderita Kanker Payudara Pasca Kemoterapi di Ruang Bedah Rumah Sakit Abdul Moeloek (RSAM) Bandar Lampung. Riskesdas 2013 prevalensi kanker di Indonesia 1,4 per 1000 atau sekitar 330.000 orang, di Provinsi Lampung mengalami peningkatan dari 0,02\% (2010), 0,04\% (2011) dan 2012 sebesar 0,04 \% (Riskesdas 2012). Data kanker payudara (RSAM) 2014 sebanyak 471 (2,7\%) pasien. Tujuan penelitian untuk mengetahui Pengaruh pemberian Booklet Kemoterapi terhadap Kemampuan Perawatan Diri Penderita Kanker Payudara Pasca Kemoterapi di Ruang Bedah Rumah Sakit Abdul Moeloek (RSAM) Bandar Lampung 2016. Penelitian dilakukan mulai tanggal 1-30 Januari 2016, desain quasi eksperimen dengan one group, pre test dan post test. Populasi 65 ibu dengan kanker payudara pasca kemoterapi, sampel sejumlah 56 responden. Analisis data dengan uji t dependent. Hasil penelitian diperoleh nilai rata-rata perilaku perawatan diri penderita kanker payudara pasca kemoterapi sebelum pemberian booklet adalah 4,70 dengan standar deviasi 1,249. Nilai rata-rata nilai perilaku perawatan diri penderita kanker payudara pasca kemoterapi setelah pemberian booklet adalah 7,82 dengan standar deviasi 1,478. Hasil uji statistik didapatkan nilai $\mathrm{p}=0,000$, berarti pada alpha $5 \%$ dismpulkan bahwa ada pengaruh yang signifikan antara perilaku perawatan diri penderita kanker payudara pasca kemoterapi sebelum dan setelah pemberian booklet kemoterapi.
\end{abstract}

Kata Kunci: Booklet, Kemoterapi, Kanker payudara.

Data World Health Organization (WHO) tahun 2013, kanker menjadi penyebab kematian nomor dua di dunia sebesar $13 \%$ setelah penyakit kardiovaskuler. Diperkirakan tahun 2030 insiden kanker mencapai 26 juta orang dan 17 juta diantaranya meninggal akibat kanker (Kemenkes, Mediakom, edisi 5, 2015). Wanita di seluruh dunia 1,2 juta terdiagnosis terkena kanker payudara, 500.000 diantaranya meninggal dunia. Di Amerika Serikat pada tahun 2012203.500 wanita telah terdiagnosis terkena kanker payudara, 54.300 terkena Dustal Carsinoma In Situ (DCIS) atau tumor jinak, dan 40.000 wanita meninggal dunia (Olfah, 2013).

Insiden kanker meningkat dari 12,7 juta kasus tahun 2008 menjadi 14,1 juta kasus tahun 
2012, sedangkan jumlah kematian meningkat dari 7,6 juta orang tahun 2008 menjadi 8,2 juta pada tahun 2012. Di Indonesia berdasarkan data riskesdas tahun 2013 prevalensi tumor/ kanker di Indonesia adalah 1,4 per 1000 penduduk atau sekitar 330.000 orang.

Kanker (neoplasma) merupakan penyebab kematian pertama di dunia. Kanker adalah suatu penyakit yang disebabkan oleh pertumbuhan selsel jaringan tubuh yang tidak normal. Sel-sel kanker kemudian menyerang dan merusak jaringan biologis lainnya, baik dengan pertumbuhan langsung di jaringan yang bersebelahan (invasi) atau dengan migrasi sel ke tempat yang jauh (metastasis) (Ghofar, 2009).

Kanker merupakan penyebab kematian nomor 7 di Indonesia. Penderita kanker tertinggi di Indonesia adalah kanker payudara dan kanker leher rahim (Kemenkes, Mediakom, edisi 5). Kanker payudara termasuk tersering ditemukan pada perempuan setelah kanker serviks. (Dharmais, 2011). Menurut Data International Agency for Research on Cancer (IARC) 2012 didapatkan insidensi kanker payudara di Indonesia 40 per 100.000 wanita, kanker leher rahim 17 per 100.000 perempuan. Berdasarkan sistem informasi RS (SIRS). Jumlah pasien rawat jalan maupun rawat inap pada kanker payudara terbanyak yaitu 12014 orang $(28,7 \%)$ dan kanker serviks 5,349 orang (12,8\%).

Kanker memiliki berbagai macam jenis dengan berbagai akibat yang timbul. Ancaman kematian dan penurunan kualitas hidup membayangi jutaan penderita kanker. Pada tahun 2008 jumlah kematian akibat penyakit kanker mencapai 58 juta jiwa. Sedikitnya 1,2 juta jiwa di Amerika Serikat didiagnosa menderita kanker setiap tahunnya. Akan tetapi incidence rate lebih banyak terjadi di negara berkembang. Indonesia sebagai salah satu negara berkembang dengan prevalensi rate penyakit kanker yang cukup tinggi (Lutfa, 2008).

Menurut data dari Kementerian Kesehatan (Kemenkes) tahun 2012 yang dikutip oleh Bakhtiar (2012) menyebutkan bahwa prevalensi kanker mencapai 4,3 banding 1.000 orang. Padahal data sebelumnya menyebutkan prevalensinya 1 banding 1.000 orang. Badan Kesehatan Dunia atau World Health Organization (WHO) dan Serikat Pengendalian Kanker Internasional atau International Union Against Cancer (UICC) tahun 2012 memprediksi, akan terjadi peningkatan penderita kanker sebesar 300 persen di seluruh dunia pada tahun 2030. Jumlah tersebut 70 persennya berada di negara berkembang seperti Indonesia.
Menurut Persatuan Ahli Bedah Onkologi Indonesia (2005) yang dikutip oleh Lutfa (2008), penatalaksanaan / pengobatan utama penyakit kanker meliputi empat macam yaitu pembedahan, radioterapi, kemoterapi dan hormonterapi. Pembedahan dilakukan untuk mengambil massa kanker dan memperbaiki komplikasi yang mungkin terjadi. Sementara tindakan radioterapi dilakukan dengan sinar ionisasi untuk menghancurkan kanker. Kemoterapi dilakukan untuk membunuh sel kanker dengan obat antikanker (sitostatika). Sedangkan hormonterapi dilakukan untuk mengubah lingkungan hidup kanker sehingga pertumbuhan sel-selnya terganggu dan akhirnya mati sendiri. Keberhasilan pengobatan ini tergantung dari ketentuan pasien dalam berobat dan tergantung pada stadiumnya.

Kemoterapi dapat membantu dalam pembuatan rencana yang realistis oleh perawat, pasien dan keluarga. Misalnya, kemungkinan untuk sembuh, hidup lebih panjang tanpa gejala/tanda kanker atau hanya meringankan gejala kanker agar pasien hidup lebih nyaman merupakan keuntungan yang melebihi risiko efek samping dan kemoterapi yang sifatnya sementara. Kemoterapi menyembuhkan lebih dari $90 \%$ pria penderita kanker buah zakar yang telah menyebar dan sekitar 98\% wanita penderita korio karsinoma atau kanker rahim (Junaidi, 2007).

Beberapa efek samping yang tidak diinginkan akan timbul selama kemoterapi. Berat ringannya efek samping kemoterapi tergantung pada banyak hal, antara lain jenis obat kemoterapi, kondisi tubuh, kondisi psikis pasien. Efek samping kemoterapi timbul karena obatobat kemoterapi sangat kuat, dan tidak hanya membunuh sel-sel kanker, tetapi juga menyerang sel-sel sehat, terutama sel-sel yang membelah dengan cepat. Efek samping dapat muncul ketika sedang dilakukan pengobatan atau beberapa waktu setelah pengobatan (Bakhtiar, 2012).

Beberapa hal yang diakibatkan oleh efek samping terapi tersebut adalah rambut rontok bahkan sampai botak dapat terjadi selama pemberian kemoterapi, gangguan pada sumsum tulang yaitu berkurangnya hemoglobin, trombosit, dan sel darah putih, membuat tubuh lemah, merasa lelah, sesak nafas, mudah mengalami perdarahan, dan mudah terinfeksi, kulit membiru/menghitam, kering, serta gatal, pada mulut dan tenggorokan terdapat sariawan, terasa kering, dan sulit menelan, adanya mual dan muntah, nyeri pada perut saluran pencernaan, produksi hormon terganggu sehingga menurunkan nafsu seks dan kesuburan (Bakhtiar, 2012). 
Berdasarkan survei dari Health Information National Trends Survey (HINTS) (2007) yang dikutip oleh Ananditha (2012) menunjukkan bahwa 12.239 pasien kanker yang menjalani kemoterapi, ditemukan efek samping yang serius dan membutuhkan perawatan darurat sebanyak $16 \%$ dari pasien. Penyebab umum rawat inap antara lain infeksi dan demam $(8 \%)$, neutropenia atau trombositopenia $(5,5 \%)$, gangguan elektrolit seperti dehidrasi $(2,5 \%)$, mual muntah $(2,9 \%)$, kelelahan, pusing atau gangguan fisik yang berhubungan dengan kondisinya $(2 \%)$, trombosis vena dalam atau emboli paru (1,2\%), dan malnutrisi $(0,9 \%)$.

Dampak dari pengobatan kanker (kemoterapi) dapat menyebabkan ketidakmampuan berjalan atau menggerakkan tangan sehingga tidak mampu melakukan pekerjaan apapun dan beraktivitas sebagaimana sebelum sakit. Keadaan ini dapat menyebabkan penilaian negatif terhadap diri sendiri dan menjadi tidak percaya diri karena jadi bergantung pada orang lain, merasa menjadi beban bagi keluarga dan merasa tidak berguna (Lubis, 2009).

Menurut Keliat (1992) yang dikutip oleh Yani (2007), bahwa hilangnya bagian badan, tindakan operasi, proses patologi penyakit, perubahan struktur dan fungsi tubuh, proses tumbuh kembang, prosedur tindakan dan pengobatan merupakan situasi atau stressor yang dapat mempengaruhi konsep diri dan komponennya yakni citra tubuh, ideal diri, harga diri, penampilan peran, dan identitas personal.

Pengobatan kanker itu sendiri memberi dampak negatif pada fisik maupun mental dan mempunyai pengaruh yang besar terhadap konsep diri. Jika konsep diri menderita, maka pikiran dan tingkah laku seseorang akan menjadi terganggu, begitu seterusnya. Mengalami kebotakan dan menyebabkan ia merasa tubuhnya tidak menarik lagi serta merasa bahwa suami tidak tertarik lagi pada dirinya. Namun gangguan harga diri pada penderita penyakit kanker, kemungkinan mengalami hubungan interpersonal yang tidak harmonis. Kondisi penderita kanker serviks stadium lanjut tidak dapat kembali ke keadaan semula, dikarenakan gangguan konsep diri yang terjadi dalam dirinya yakni kecacatan tubuh dan penurunan fungsi organ tubuh (Lubis, 2009).

Penelitian yang dilakukan oleh Saraswati (2009) di Ruang Rawat Inap RSUP Dr. Kariadi Semarang dengan menggunakan 30 orang pasien kanker yang telah mendapat kemoterapi sebagai responden, yang hasil penelitiannya menunjukkan bahwa sebagian besar konsep diri responden yang menghadapi kemoterapi tergolong sedang yaitu sebesar (87\%), konsep diri responden tergolong tinggi (13\%) sedangkan proporsi terkecil yang mendapat kemoterapi adalah konsep diri yang tergolong rendah yaitu $(0 \%)$. Dapat disimpulkan bahwa konsep diri penderita kanker yang mendapat kemoterapi di Ruang Rawat Inap RSUP Dr. Kariadi Semarang tergolong sedang.

Penelitian yang dilakukan oleh Lutfa (2008) pada awal bulan Oktober 2007 dengan melakukan wawancara terhadap pasien kanker yang menjalani kemoterapi di ruang Cendana 1 RSUD Dr. Moewardi sebanyak 34 responden, yang hasil penelitiannya menunjukkan bahwa sebagian besar pasien rambutnya menjadi rontok, merasa mual dan muntah, $25 \%$ pasien merasakan perannya sangat berkurang. Pasien laki-laki merasa tidak mampu lagi menghidupi keluarga, tidak mampu berdekatan dengan anak dan mengurusnya.

Penderita kanker payudara di Indonesia tahun 2013 berdasarkan profil Kesehatan Indonesia tahun 2008 terlihat perubahan angka, pada tahun 2005 jumlah penderita kanker payudara 7.850 kasus, tahun 2006 meningkat menjadi 8.328 kasus, tahun 2007 sedikit penurunan menjadi 8.277, dan tahun 2008 sebanyak 5.207 kasus. Data ini adalah data penderita kanker payudara yang merupakan pasien yang rawat inap dengan diagnosis kanker. Jadi penderita kanker payudara sebenarnya sangat mungkin jauh lebih besar lagi (Kemenkes, Mediakom, edisi 5).

Menurut Ekowati (2013) lebih dari 40\% dari semua kanker dapat dicegah, bahkan beberapa jenis yang paliing umum seperti kanker payudara, kolorektal dan leher rahim dapat disembuhkan jika terdeteksi dini (Kemenkes, Mediakom, edisi 5). Menurut Age standardized cancer ratio (ASCAR) 2005 kasus kanker payudara di Indonesia terbanyak menyerang kelompok umur 45-54 dengan nilai ASCAR $17,38 \%$. Di Indonesia problem kanker payudara menjadi lebih besar lagi karena lebih dari $70 \%$ penderita datang ke dokter pada stadium yang sudah lanjut, maka dari itu permasalahan mengenai kanker payudara memang membutuhkan perhatian khusus (Saryono, 2009). Penelitian yang dilakukan oleh Anggorowati (2012) menjelaskan bahwa kasus kanker payudara di Indonesia terus meningkat sepanjang tahun 2009-2012 dengan kejadian 5.297 kasus di tahun 2009, 7.850 kasus di tahun 2010, 8.328 kasus di tahun 2011, dan 8.277 kasus di tahun 2012.

Prevalensi kasus kanker payudara di Provinsi Lampung mengalami peningkatan dari 
0.02\% pada tahun 2010 menjadi $0.04 \%$ tahun 2011 dan pada tahun 2012 tetap sebesar $0.04 \%$ (Riskesdas 2012). Kasus penyakit Kanker payudara tahun 2012-2013 yang ditemukan di Provinsi Lampung sebanyak 1.030 kasus, dimana Lampung Barat 103 (10\%) kasus, diikuti Pringsewu 102 (9,8\%) kasus, Way Kanan 98 (9,5\%) kasus, Metro 94 (9,1\%) kasus, Provinsi Lampung 89 (8,6\%) kasus, Lampung Selatan 89 $(8,6 \%)$ kasus, Lampung Utara 81 (7,8\%) kasus, Mesuji 79 (7,6\%) kasus, Lampung Timur 76 $(7,3 \%)$ kasus, Tanggamus $72(6,9 \%)$ kasus, Lampung Tengah 67 (6,5\%) kasus, Pesawaran 53 $(5,1 \%)$ kasus, Tulang Bawang 51 (4,9\%) kasus, Tulang Bawang Barat $50(4,8 \%)$ kasus dan Kabupaten Pesisir Barat 17 (1,6\%) kasus. (Dinas Kesehatan Provinsi Lampung, 2012).

Data Kanker payudara yang dikeluarkan oleh tim penanganan kanker Rumah Sakit Umum Daerah Abdul Moeloek (RSUDAM) sesuai data Instalasi Patologi Anatomik (PA) rumah sakit tipe B pendidikan tersebut, sebanyak 597 (3,6\%) pasien terdiagnosis menderita kanker payudara pada tahun 2013, tahun 2014 sebanyak 471 $(2,7 \%)$ pasien dan tahun 2013 terdiagnosis sebanyak $605(5,3 \%)$ pasien. Tahun 2015 berdasarkan hasil penelitian Windarti, di Rumah Sakit Abdul Moeloek ditemukan penderita carcinoma yang terjadi pada usia muda sebagian besar memiliki tipe histologi duktal invasive grade inti 3 invasi ke pembuluh limfe dan telah terjadi metastasis.

Beberapa penelitian yang dilakukan hanya melihat hubungan antara faktor risiko dengan terjadinya kanker payudara, tanpa melihat bagaimana pengaruh kemoterapi terhadap efek samping yang dialami klien. Berdasarkan uraian di atas peneliti tertarik untuk meneliti pengaruh pemberian booklet kemoterapi terhadap kemampuan perawatan diri penderita kanker payudara pasca kemoterapi di ruang bedah RSAM Provinsi Lampung tahun 2016.

Sehingga diperoleh manfaat dari penelitian ini yaitu memberikan pemahaman tentang upaya rehabilitatif dalam merawat diri terhadap efek samping kemoterapi pada penderita kanker payudara secara mandiri sehingga dapat meningkatkan kualitas hidup penderita melalui bukti empiris. Sebagai bahan masukan kepada institusi pelayanan kesehatan, pendidikan kesehatan untuk dapat meningkatkan upaya rehabilitatif terutama dalam pemulihan dari efek samping akibat kemoterapi.

\section{METODE PENELITIAN}

Jenis penelitian ini yaitu penelitian kuantitatif, yang dilaksanakan tanggal 1-30 Januari 2016. Lokasi penelitian di ruang Bedah Wanita Rumah Sakit Abdul Moeloek Provinsi Lampung. Desain penelitian adalah quasi eksperimen dengan one group, pre test dan post test. Populasi penelitian 65, sampel penelitian sejumlah 56 responden (tabel penentuan jumlah sampel menurut Stephen Isaac dan Willliam B. Michel dalam Silalahi 2012. Analisis data menggunakan uji $\mathrm{T}$ dependen.

\section{HASIL PENELITIAN}

Berdasarkan hasil analisis statistik, hasil penelitian dapat diuraikan sebagai berikut:

Tabel 1. Rerata kemampuan perawatan diri sebelum dan setelah pemberian booklet perawatan diri pasca kemoterapi pada penderita kanker payudara

\begin{tabular}{llll}
\hline Variabel & mean & SD & SE \\
\hline $\begin{array}{l}\text { Kemampuan perawatan } \\
\text { diri penderita kanker }\end{array}$ & & & \\
pasca kemoterapi & & & \\
- Sebelum pemberian & & & \\
$\quad$ booklet & 4,70 & 1,249 & 0,167 \\
- Setelah pemberian & & & \\
$\quad$ booklet & 7,82 & 1,478 & 0,198 \\
\hline
\end{tabular}

Nilai rata-rata perilaku perawatan diri penderita kanker payudara pasca kemoterapi sebelum pemberian booklet adalah 4,70 dengan standar deviasi 1,249. Rata-rata nilai perilaku perawatan diri penderita kanker payudara pasca kemoterapi setelah pemberian booklet adalah 7,82 dengan standar deviasi 1,478 .

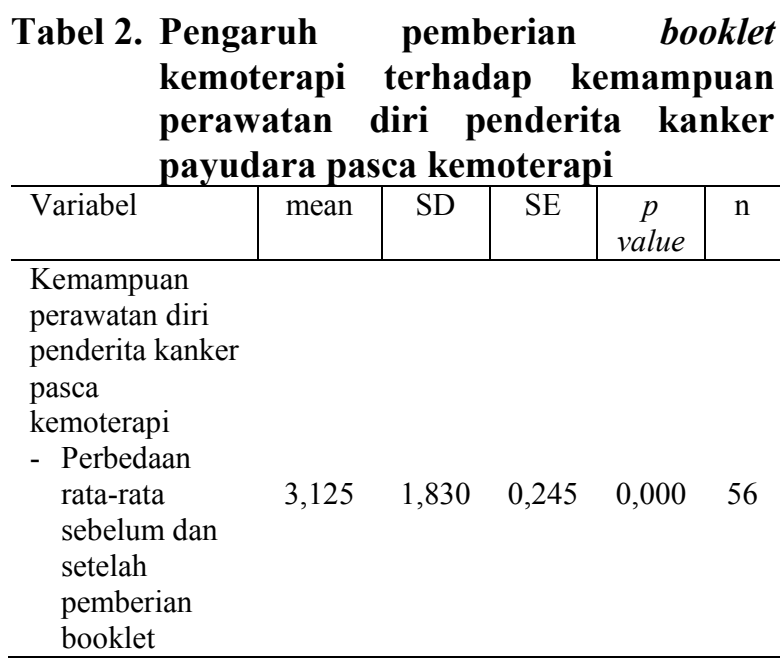


Nilai rata-rata perbedaan perilaku perawatan diri penderita kanker payudara pasca kemoterapi sebelum dan setelah pemberian booklet adalah 3,125 dengan standar deviasi 1,830. Hasil uji statistik didapatkan nilai $\mathrm{p}=$ 0,000 , berarti pada alpha $5 \%$ terlihat bahwa ada pengaruh yang signifikan antara perilaku perawatan diri penderita kanker payudara pasca kemoterapi sebelum dan setelah pemberian booklet kemoterapi.

\section{PEMBAHASAN}

Rata-rata kemampuan perawatan diri penderita kanker payudara pasca kemoterapi sebelum pemberian booklet

Hasil penelitian diperoleh nilai rata-rata perilaku perawatan diri penderita kanker payudara pasca kemoterapi sebelum pemberian booklet adalah 4,70 dengan standar deviasi 1,249. Hasil penelitian sesuai uraian dari Unicef (2010) yang menjelaskan bahwa tahapan perubahan perilaku diawali dari tidak sadar atau tidak tahu. Hasil penelitian juga sesuai dengan teori edukasi Setiawati (2008) yang menyatakan bahwa edukasi merupakan proses belajar dari tidak tahu tentang nilai kesehatan menjadi tahu dan dari tidak mampu mengatasi kesehatan sendiri menjadi mandiri (Suliha, 2002).

Hasil penelitian ini juga sesuai dengan penelitian yang Hidayati, Trixie dan Istiana (2011), yang menunjukkan bahwa pengetahuan sebelum penyuluhan rata-ratanya lebih rendah dibandingkan dengan pengetahuan setelah penyuluhan tentang kanker payudara, penelitian Herniyatun, Astutiningrum dan Nurlaila (2009), yang menyatakan ada perbedaan yang signifikan rata-rata nilai pengetahuan, sikap, ketrampilan antara sebelum dan setelah diberikan penyuluhan tentang pencegahan kanker serviks.

Berdasarkan pembahasan di atas maka dapat disimpulkan bahwa skor hasil penelitian sebelum pemberian booklet, nilainya lebih rendah dibandingkan setelah pemberian booklet. Nilai rerata responden sebelum pemberian booklet rendah atau dapat diklasifikasikan berpengetahuan kurang sehingga kemampuan merawat dirinya juga kurang.

\section{Rata-rata kemampuan perawatan diri penderita kanker payudara pasca kemoterapi setelah pemberian booklet}

Hasil penelitian diperoleh nilai rata-rata nilai perilaku perawatan diri penderita kanker payudara pasca kemoterapi setelah pemberian booklet adalah 7,82 dengan standar deviasi 1,478.
Hasil penelitian sesuai dengan teori edukasi Setiawati (2008) yang menyatakan bahwa edukasi merupakan serangkaian upaya yang ditujukan untuk mempengaruhi orang lain, mulai dari individu, kelompok, keluarga dan masyarakat agar terlaksananya perilaku hidup sehat. Edukasi merupakan satu bentuk intervensi mengubah perilaku secara terencana untuk membantu klien baik individu, kelompok, maupun masyarakat dalam mengatasi masalah kesehatannya melalui kegiatan pembelajaran, untuk dapat lebih mandiri dalam mencapai hidup sehat. Tujuan edukasi adalah untuk mengubah pemahaman individu, kelompok, dan masyarakat di bidang kesehatan agar menjadikan kesehatan sebagai sesuatu yang bernilai, mandiri dalam mencapai tujuan hidup sehat, serta dapat menggunakan fasilitas pelayanan kesehatan yang ada dengan tepat dan sesuai (Suliha, 2002).

Penelitian Sirait, Rustina dan Waluyanti, (2013) hasil penelitian menjelaskan bahwa adanya peningkatan secara bermakna pada kelompok intervensi dalam aspek pengetahuan, sikap dan ketrampilan dalam penanganan demam. Penelitian Terok dan Wingkana (2012), Hasil analisis pada kelompok perlakuan setelah diberikan bimbingan mental terjadi peningkatan signifikan terhadap perkembangan perilaku biopsikososial neonates. Halimatusakdiah dan Nurhayati (2014), hasil penelitian menunjukkan ada perbedaan pemahaman dan ketrampilan tentang deteksi dini demam pada bayi sebelum dan sesudah diberikan penyuluhan.

Berdasarkan uraian di atas peneliti menyimpulkan bahwa kemampuan seseorang akan meningkat jika memperoleh informasi, sehingga berbagai media diperlukan terutama booklet. Bentuk informasi yang dibuat dalam bentuk booklet sangat menarik perhatian dikarenakan berisi informasi singkat, lengkap dan dapat dibaca ulang oleh penderita jika ditemukan permasalahan kesehatan.

\section{Pengaruh pemberian booklet kemoterapi terhadap kemampuan perawatan diri penderita kanker payudara pasca kemoterapi}

Hasil uji statistik didapatkan nilai $\mathrm{p}=$ 0,000 , berarti pada alpha $5 \%$ terlihat bahwa ada pengaruh yang signifikan antara perilaku perawatan diri penderita kanker payudara pasca kemoterapi sebelum dan setelah pemberian booklet kemoterapi. Hasil penelitian menunjukkan kesesuaian dengan teori yang dikemukakan oleh Notoatmodjo 2010, tentang perilaku kesehatan yang merupakan suatu respons seseorang terhadap stimulus atau objek yang berkaitan dengan sakit dan penyakit, sistem 
pelayanan kesehatan, makanan dan minuman, serta lingkungan.

Selanjutnya Notoatmodjo

mengklasifikasikan perilaku kesehatan menjadi tiga kelompok yaitu:

1. Perilaku pemeliharaan kesehatan

Perilaku pemeliharaan kesehatan yang meliputi tiga aspek:

a. Perilaku pencegahan penyakit, dan penyembuhan penyakit bila sakit, serta pemulihan kesehatan bilamana telah sembuh dari penyakit.

b. Perilaku peningkatan kesehatan, apabila seseorang dalam keadaan sehat perlu diupayakan supaya mencapai tingkat kesehatan optimal.

c. Perilaku gizi (makanan dan minuman). Makanan dan minuman dapat memelihara dan meningkatkan kesehatan seseorang.

2. Perilaku pencarian dan penggunaan sistem atau fasilitas pelayanan kesehatan, atau sering disebut perilaku pencarian pengobatan. Perilaku ini menyangkut upaya atau tindakan seseorang pada saat menderita penyakit atau kecelakaan.

3. Perilaku kesehatan lingkungan. Bagaimana seseorang merespon lingkungan, baik fisik, sosial budaya sehingga lingkungan tersebut tidak mempengaruhi kesehatannya.

Notoatmodjo (2007) menjelaskan perubahan perilaku baru dalam kehidupannya melalui tiga tahap yaitu pengetahuan, sikap dan praktik/ tindakan. Teori perubahan perilaku kesehatan ini mendasari praktik pelayanan kesehatan yang berupaya untuk mengubah perilaku masyarakat agar pro aktif dalam mencari pelayanan kesehatan, terutama bagi mereka yang berisiko menderita penyakit keganasan seperti kanker payudara. Berbagai terapi kanker payudara dapat juga mengakibatkan komplikasi atau berbagai permasalahan kesehatan lainnya, untuk itu diperlukan upaya memandirikan klien dalam perawatan diri.

Hasil penelitian ini juga sesuai dengan teori preced-proceed (Lawrence Green, 2005), perilaku kesehatan ditentukan oleh faktor: predisposing factors, terwujud dalam pengetahuan, sikap, kepercayaan, keyakinan, nilai. Enabling factors, tersedianya atau tidak tersedianya fasilitas. Reinforcing factors, terwujud dalam sikap dan perilaku petugas kesehatan atau dari perilaku masyarakat.

Pendidikan kesehatan melalui booklet mempunyai 3 tujuan dalam upaya meningkatkan kemampuan klien secara mandiri dalam perawatan diri, sesuai dengan teori, yaitu : 1)
Cure (pengobatan kemoterapi, 2) Control penyakit, dan 3) Palliation (mengurangi gejala dan meningkatkan kualitas hidup dari pasien).

Terapi dengan menggunakan obat terutama ditujukan untuk meningkatkan kualitas atau mempertahankan hidup pasien. Dalam pemberian obat, kemungkinan dapat terjadinya masalah terkait dengan obat yang tidak diharapkan, salah satunya adalah efek samping dari pemberian suatu obat. Setiap obat mempunyai kemungkinan untuk menyebabkan efek samping obat (ESO), karena seperti halnya efek farmakologi, efek samping obat juga merupakan hasil interaksi antara molekul obat dengan sistem biologik tubuh. Resiko efek samping obat tidak dapat dihilangkan, tetapi dapat ditekan dan dikurangi seminimal mungkin dengan mengetahui kondisi yang mendorong terjadinya efek samping, mengetahui sifat obat, serta mengetahui cara pemakaian yang tepat. Faktor resiko yang mendorong terjadinya efek samping dapat berasal dari individu pasien, misalnya fisiologik (umur, konstitusi tubuh,jenis kelamin, faktor patologi, faktor alergik, faktor genetik). Faktor resiko juga dapat berasal dari obat, misalnya obat, formulasi, kemurnian, dosis,dan frekuensi pemberian.

Prosedur pelaksanaan kemoterapi di RSAM telah dilakukan sesuai prosedur yang ditentukan, terutama saat inform consent, hanya saja pada mereka yang mendapatkan booklet tampak lebih tenang menghadapi kemoterapi karena mendapatkan pengetahuan secara lisan dan tertulis. Edukasi booklet dalam penelitian ini mempunyai tujuan yang sama dengan tujuan edukasi menurut Notoatmodjo (2010) yaitu 1) menjadikan kesehatan sebagai sesuatu yang bernilai di masyarakat, 2) menolong individu agar mampu secara mandiri atau berkelompok mengadakan kegiatan untuk mencapai hidup sehat, 3) mendorong pengembangan dan penggunaan secara tepat sarana pelayanan kesehatan yang ada.

Tujuan edukasi di atas adalah untuk mengubah pemahaman individu, kelompok, dan masyarakat di bidang kesehatan agar menjadikan kesehatan sebagai sesuatu yang bernilai, mandiri dalam mencapai tujuan hidup sehat, serta dapat menggunakan fasilitas pelayanan kesehatan yang ada dengan tepat dan sesuai (Suliha, 2002).

Hasil penelitian ini juga mendukung penelitian sebelumnya seperti penelitian Hidayati, Trixie dan Istiana (2011), yang menyatakan ada perbedaan pengetahuan sebelum dan setelah penyuluhan dengan $z=6,456(p=$ $0,000)$ dan ada perbedaan ketrampilan siswi melakukan SADARI dengan $t$ hitung sebesar 
48,252 ( $\mathrm{p}=0,000)$. Hasil penelitian ini juga memperkuat penelitian Herniyatun, Astutiningrum dan Nurlaila (2009), dengan hasil penelitian ada perbedaan yang signifikan rata-rata nilai pengetahuan $(p=0,000)$, sikap $(p=0,024)$, ketrampilan $(\mathrm{p}=0,000)$ antara sebelum dan setelah pada kelompok perlakuan. Hasil penelitian juga menunjukkan bahwa antara kelompok perlakuan dan kontrol ada perbedaan yang signifikan rata-rata nilai sikap $(\mathrm{p}=0,027)$, keterampilan $(\mathrm{p}=0,000)$, tetapi tidak signifikan untuk pengetahuan $(\mathrm{p}=0,150)$. Edukasi peer group akan bisa merubah perilaku pencegahan kanker serviks jika dilakukan oleh kader kesehatan yang terpilih, yang bisa mentransfer ilmu tentang pencegahan ini secara tuntas, sehingga tidakhanya sikap dan ketrampilan yang bisa berubah tetapi pengetahuan yang luas tentang kanker servik juga bisa dimiliki oleh semua anggota peer group yang ada di masyarakat Kebumen.

Hasil penelitian ini juga menjelaskan bahwa edukasi penting dilakukan dalam upaya pencegahan komplikasi penyakit lebih lanjut, hal ini sesuai dengan penelitian Soep (2011), dengan hasil penelitian terjadi penurunan depresi postpartum sebesar $65 \%$ dan terdapat perbedaan depresi postpartum pada ibu yang dilakukan intervensi psikoedukasi dengan ibu yang tidak dilakukan intervensi psikoedukasi dan penelitian Sumiatun (2013), dengan hasil penelitian yang menjelaskan ada hubungan antara pengetahuan dengan upaya pencegahan kanker payudara pada wanita usia subur di desa Ngino kecamatan Semanding Tuban tahun 2013, dengan koefesien korelasi 0,679 yang berarti mempunyai kemaknaan kuat.

Berdasarkan uraian di atas disimpulkan bahwa ada pengaruh yang signifikan antara pemberian booklet kemoterapi terhadap

\section{DAFTAR PUSTAKA}

Ananditha, Aries Chandra. 2012. PACE, PCM, \& CSN: Teknologi E/Tablet untuk Anak Penderita Kanker yang BerinisiatifTinggi. http://ads.kompasads.com/ diakses 1 Oktober 2015.

Ariawati, K. 2007. Toksisitas Kemoterapi Leukemia Limfoblastik Akut pada Fase Induksi dan Profilaksis Susunan Saraf Pusat dengan Metroteksat 1 gram. Sari Pediatri Vol. 9, No. 4, Desember.

Arikunto, Suharsimi. 2006. Prosedur Penelitian. Jakarta: Rineka Cipta. kemampuan penderita dalam perawatan diri. Mengingat pentingnya upaya dalam memandirikan penderita dan mencegah komplikasi lebih lanjut, maka pemberian booklet kemoterapi dapat menjadi alternatif dalam memberikan pendidikan kesehatan, mengingat keterbatasan tenaga kesehatan untuk memberikan pendidikan kesehatan secara langsung dan keseragaman informasi. Untuk itu diperlukan dukungan dari fihak manajemen rumah sakit untuk memfasilitasi ketersediaan booklet di ruang kemoterapi. Institusi pendidikan dalam setiap mata kuliah, hendaknya juga mengembangkan berbagai bentuk media kreatif dan inovatif yang dapat digunakan mahasiswa dalam memberikan pendidikan kesehatan kepada klien dan keluarga. Penelitian lebih lanjut dapat dilakukan dengan meneliti beberapa faktor lain dan media elektronik yang lebih menarik dalam upaya pencegahan dan rehabilitasi penderita yang menjalani kemoterapi.

\section{SIMPULAN}

Nilai rata-rata perilaku perawatan diri penderita kanker payudara pasca kemoterapi sebelum pemberian booklet adalah 4,70 dengan standar deviasi 1,249. Nilai rata-rata nilai perilaku perawatan diri penderita kanker payudara pasca kemoterapi setelah pemberian booklet adalah 7,82 dengan standar deviasi 1,478. Hasil uji statistik didapatkan nilai $\mathrm{p}=0,000$, berarti pada alpha 5\% terlihat bahwa ada pengaruh yang signifikan antara perilaku perawatan diri penderita kanker payudara pasca kemoterapi sebelum dan setelah pemberian booklet kemoterapi.

Bakhtiar. 2012. Manfaat \& Efek Samping Kemoterapi. http:// Manfaat dan efek sampingkemoterapi_Bakhtiar.htm diakses tanggal 1 Oktober 2015.

Carpenito, Lynda Juall. 2001. Buku Saku Diagnosa Keperawatan. Edisi 8. Jakarta: EGC.

Ghofar, Abdul. 2009.Cara Mudah Mengenal \& Mengobati Kanker. Jogjakarta: Flamingo.

Hadiyanto, Yanwar et al. (2012). Health First. Jakarta: PT. Mesa Publishing.

Hidayat, A. A. 2009. Pengantar Konsep Dasar Keperawatan. Jakarta: Selemba Medika. 
Janewinarni. 2011. Perilaku Klien Dengan Gangguan Konsep Diri. Diakses di http://janewinarni.wordpress.com/ diakses 08 Mei 2013.

Junaidi, Iskandar. 2007. Kanker. Jakarta: PT Bhuana Ilmu Populer.

Lubis, N. Hasnida. 2009. Terapi Perilaku Kognitif pada Pasien Kanker. Medan : USU Press.

Lutfa, Umi. 2008. Faktor-faktor yang Mempengaruhi Tingkat Kecemasan Pasien dengan Tindakan Kemoterapi di Ruang Cendana RSUD Dr. Moewardi Surakarta. http://etd.eprints.ums.ac.id/ diakses 22 September 2012.

Mubarak, Wahit Iqbal. 2007. Buku Ajar Kebutuhan Dasar Manusia: Teori dan Aplikasi dalam Praktik. Jakarta: EGC.

Notoatmodjo,S. 2007. Promosi Kesehatan dan Ilmu Perilaku. Jakarta: Rineka Cipta 2010. Metodologi Penelitian Kesehatan. Jakarta: Rineka Cipta.
Rasjidi, Imam. 2007. Kemoterapi Kanker Ginekologi Dalam Praktik Sehari-hari. Malang: Sagung Seto.

Rola, F. 2006. Hubungan Konsep Diri Dengan Motivasi Berprestasi Pada Remaja. http://www.digitizedlibrary.usu.ac.id diakses 22 November 2015.

Saraswati, Sri Haryani. 2009. Jurnal Keperawatan dan Kebidanan: Hubungan antara Kecemasan pada Penderita Kanker yang Mendapat Kemoterapi dengan Konsep Diri. Jurnal Keperawatan dan Kebidanan (JIKK) Vol.I, No.1 Desember.

Stuart, G. W. 2007. Buku Saku Keperawatan Jiwa. Edisi 5. Jakarta: EGC.

Trismiati. 2004. Jurnal Psyche: The Anxiety Level Differences Among Male and Female Sterilization Acceptors at RSUP Dr. Sardjito Yogyakarta. Vol. 1 No. 1, Juli.

Yani, Desy Indra. 2007. Pengalaman Hidup Klien Kanker Serviks di Bandung. http://resources.unpad.ac.id/diakses 24 September 2012. 